\title{
Improvement of Mathematics Learning Outcomes by Applying The Missouri Mathematics Project Learning Model And Dienes Game Theory
}

\section{Muhammad Fakhri, Marhan Taufik, Agung Deddiliawan Ismail}

\author{
Mathematics Education, Faculty of Teacher Training and Education, University of \\ Muhammadiyah Malang \\ E-mail: muhammadfakh66@ gmail.com
}

\begin{abstract}
Based on the results of first observations and interviews with class teachers at SMP Negeri 06 Batu, mathematics learning outcomes for class VIIA students in the End Semester Test (EST) even semester of the 2018/2019 school year had an average grade below the Minimum Criteria of Mastery Learning (MCML) and only about 5 students reached MCML. This research aims to improve the mathematics learning outcomes of Grade VIII A students by applied the Missouri Mathematics Project (MMP) learning model combined with Dienes Game Theory. This research method used the Classroom Action Research (CAR) method with application for 4 meetings in 2 cycles. Each cycle there are 4 stages: planning, implementing, observing, and reflecting. Data collection techniques used tests, interviews, observations, and document studies. Data collection techniques used were tests, interviews, observations, and document studies. The results showed that by applying the MMP learning model combined with Dienes Games Theory, it could improve mathematics learning outcomes for students of class VIII A. The results of EST grade VII A students as the initial reference were 73,8 , to 84.8 in cycle 1 , and 86.0 in cycle 2 .

Keywords: Missouri Mathematics Project; Dienes Game Theory; Learning Outcomes
\end{abstract}

\section{INTRODUCTION}

Education is an effort made consciously by teachers and students in an educational environment (school) so students can explore and discover the exists potential each other. Students also expected to have strong religious values, intelligence and accuracy in thinking, discipline, social attitudes, good personality, and skills that can make students unique and have a value in society. All Indonesian citizens have equal rights to get a quality education (Law Number 20 Year 2003 article 5 (1)). But in reality, a quality education system cannot be felt by all Indonesian citizens, especially in remote areas or border areas. Equitable Education system that has not been maximized is also felt by schools that have just been established in one place (Hakim, 2016), which makes these students carry out learning activities in modest. The aspects that have caused the distribution of education in Indonesia have not been maximized are reionization, a very high school entrance standard, differences in educational facilities, uneven distribution of schools, and different socioeconomic values of the community (Idrus, 2012).

Classroom learning supported by various supporting components influences the learning process and outcomes. The components include teacher professionalism, human resources, school administration, and infrastructure. Permendiknas No. 24/2007 explains that the maximum number of students who occupy one classroom is 32 students (Karwati, 2015). Its practice in schools there are still more than 32 students in one class. This happens because of limited classrooms that can affect student concentration during the 
learning process. The classroom conditions that have too many students also cause the teacher to not be optimal in paying attention to the difficulties encountered by students. Other learning support components besides infrastructure are teacher professionalism and human resources (students). The right step when schools are not supported by adequate infrastructure is to optimize the ability of teachers and school administration systems. Such conditions require teachers to work extra and professionally. The teacher can be said as one of the important factors to determine whether or not the quality of learning in the classroom (Sanjaya, 2015). The performance of a teacher can be assessed from the readiness in preparing the Learning Implementation Plan (RPP), the implementation of the learning process in the classroom, and from the results of the evaluation of learning. How the teacher conveys knowledge to students also determines the learning outcomes obtained (Thobroni, 2015).

Ways to teach teachers to include the use of approaches, strategies, models and learning methods. The use of models and methods in the classroom varies according to learning needs. The learning process in class with interactive learning methods and models will increase student interest in learning, so students can understand the material delivered by the teacher and the learning outcomes obtained. The learning model is a learning framework that is used as a guide for teachers to carry out learning activities in class. The selection of learning models is adjusted to the subjects that will be delivered by the teacher. Subjects that are still considered difficult to convey the intent of the material to students by some teachers in Indonesia are mathematics. $11.35 \%$ of teachers in Indonesia still cannot explain a question posed by students directly when learning in class (Karimah, 2018). This is why some teachers still consider mathematics as a difficult learning material. Material on mathematics includes theories, concepts, algebraic operations, and many others. To convey the materials that there are various ways have been done by most of the teachers such as modifying various learning models, the use of teaching materials, learning media, and conditioning the classroom situation. In reality, these steps still cannot have a significant effect on the learning process. Difficulties that occur not only from teacher factors, but several factors make it difficult for students to accept mathematical material such as physiological, social, emotional, and intellectual factors.

Initial observations were carried out by researchers at the 06 Batu Junior High School (SMP) on February 22, 2019. The SMP is a school that can be categorized as a new school. Batu 06 Middle School has only been running the learning and learning process for approximately 8 years based on the Decree of the operational permit in the Ministry of Education and Culture DAPODIKDASMEN in 2019. As schools that have just been operating in a not too long period, SMP Negeri 06 Batu is still not sufficient for infrastructure, human resources, and teaching staff. This condition affects the value of student learning outcomes. Aside from the school environment factor, the support factor from parents was also felt to be lacking for students in SMP Negeri 06 Batu so that it further aggravated the existing conditions.

The learning process in SMP Negeri 06 Batu is still very dependent on the way a teacher teaches in class. Teachers at SMP Negeri 06 Batu are required to be able to make learning in the class active and interesting for students, but this situation cannot continue because students need other tools such as models and learning media. Mathematics learning at SMP Negeri 06 already uses the Cooperative Learning model, but still uses one type of learning model that is "STAD" by using the media "Plano Blank" which sometimes makes students bored with mathematics learning itself. Blank Plano is a media made of frosted Plano paper measuring $90 \times 120 \mathrm{~cm}$ used to attach the work of students 
(groups/individuals) that is most quickly completed and correct when learning in class. Mathematics teaches about concepts, problems, and mathematical problems so students can solve all problems systematically. Students need high concentration to understand various mathematical materials correctly. High concentration will not be obtained if students are not in comfortable conditions.

The researcher tries to give a new picture to the teacher about an interesting and active learning model to encourage students to be more interested in mathematics. Combining the MMP (Missouri Mathematics Project) learning model where this learning model requires students to be more independent in the process of learning mathematics. The learning model is slightly different from the cooperative learning model, this MMP model demands students to be active but the teacher is also required to guide students in solving the problems given. Introduction, Development, Training With Teacher Guidance, Independent Work, and Closing are the steps of the MMP learning model. Combined with Dienes game theory, this learning theory assumes that learning with structured games will increase students' understanding and value of learning outcomes. Dienes game theory emphasizes students to be able to interact directly with the game actively. Free Play, Games, Searching for commonalities, Representation, Symbolization, Formalization are steps to implement the theory of learning dienes in class. The author will try to research for "Improving Mathematics Learning Outcomes By Applying the Missouri Mathematics Project Learning Model and Dienes Theory of Dienes in 06 State Junior High School Batu".

The formulation of the problem in this study is "How is the learning process in class VIII A by applying the MMP Learning Model combined with the Dienes Game Theory in 06 State Junior High School Batu", and "Does mathematics learning by applying the MMP Learning Model combined with the Dienes Game Theory can improve student learning outcomes in SMP Negeri 06 Batu ". The purpose of this study is "To find out how the learning process in the classroom by applying the MMP Learning Model combined with Dienes Game Theory in 06 State Junior High School", and "To find out after the implementation of the MMP Learning Model combined with the Dienes Game Theory in 06 State Junior High School Batu an increase or not".

This research has benefits as an alternative learning that can be used by teachers. Students become more independent, interactive when learning, and better understand the material when learning and the value of mathematics learning outcomes will be better. Provide knowledge about how to create interesting and innovative learning processes for researchers.

The limitation of the problem in this study is that the class used research is centered on only one class, namely class VIII A. Because according to teachers in class VIII A, the class gets the lowest average mathematics learning outcomes compared to other classes. Improved student learning outcomes under study are in the cognitive domain score only.

\section{RESEARCH METHODS}

This research was carried out based on the existing problems at SMP Negeri 06 Batu, where the school was still classified as a new school. Requires a varied learning model so that students do not get bored and do not have an impact on the value of student learning outcomes. This research uses Classroom Action Research with quantitative and qualitative approaches. Quantitative research data in the form of average students' independent test scores after learning using the MMP learning model combined with Dienes Game Theory. The subjects in this study were students of class VIII A, SMP Negeri 06 Batu, while the 
object of this study was the student learning outcomes grade VIII A SMP Negeri 06 Batu. The instruments used in this study were observation sheets, document studies, interviews, and tests. The data analysis technique in this research is a quantitative data analysis technique that is calculating the average score and qualitative data that is reduction, presentation, and data verification.

\section{RESULTS AND DISCUSSION}

This research is a CAR that was carried out in Batu 06 Middle School in class VIII A from July 23 to August 2, 2019. The number of students in class VIII A was 32 students with 16 students and 16 students. This research was conducted in 2 cycles and each cycle consisted of 2 meetings, which means this research was carried out for 4 meetings. During the 2 weeks of this research, the learning process was adjusted to the schedule of mathematics subjects for Tuesday 23 and 30 July for $3 \times 40$ minutes. While on Friday 26 July and 2 August for $2 \times 40$ minutes. The focus of this research is the learning process and student learning outcomes scores. Student learning outcomes scores are obtained from individual student tests. The purpose of this study was carried out for 2 cycles is to find out how the learning process using MMP learning models combined with Dienes Game Theory and find out whether there is an increase in the value of mathematics learning outcomes for students of class VIII A using MMP learning models combined with Dienes Game Theory. In cycle 1 there was an increase in the value of learning outcomes and cycle 2 the same was true even though the increase from cycle 1 to 2 was not very significant.

Learning outcomes scores obtained by students when the EST used as a reference value in this study and scores of student learning outcomes in cycles 1 and 2 are as follows:

Table 1 Average of Student Learning Outcomes Grade VIII A

The Average of Student Learning Outcomes Scores Using the MMP (Missouri Mathematics Project) Learning Model \& Dienes Game Theory in 06 State Junior High School Batu

\begin{tabular}{llcccc}
\hline \multirow{2}{*}{} & \multirow{2}{*}{ EST Value } & \multicolumn{3}{c}{ Student Learning Outcomes Scores } \\
\cline { 3 - 6 } & & \multicolumn{2}{c}{ Cycle 1 } & \multicolumn{2}{c}{ Cycle 2 } \\
\cline { 3 - 6 } & & First meeting & Second meeting & First meeting & Second meeting \\
\hline \multirow{2}{*}{ AVERAGE } & 73,8 & 83,5 & 86,1 & 82,9 & 89,1 \\
\cline { 3 - 6 } & & \multicolumn{2}{c}{84,8} & 86,0 \\
\hline
\end{tabular}

By carrying out learning activities using the MMP learning model combined with Dienes Game Theory, games and discussions with groups can make students understand the material being taught. Students' understanding of the material is tested by working on individual test questions independently. The score of the individual test progresses with each cycle. Cycle 1 with a value of 84.8 increased by $11 \%$ from the reference value, namely a value of 73.8. Cycle 2 with a value of 86.0 increased by $1.2 \%$ from cycle 1 . The results obtained by researchers following previous studies conducted by M. Zainal Arifin in 2010 and Siti Atiqoh in 2014 that the MMP Learning Model and Dienes Game Theory can increase the value of student learning outcomes. In addition to giving an impact on the average score of student learning outcomes, learning with the MMP learning model and Dienes Theory also impacts students to get a score of learning outcomes that reach MCML. Student learning outcomes scores that reach MCML are presented in the table below: 
Table 2 Comparis on of Student Completeness Against MCML

\begin{tabular}{lcrrrr}
\hline Explanation & \multicolumn{2}{c}{ amount } & \multicolumn{3}{c}{ Persentase } \\
\cline { 2 - 6 } & Cycle 1 & Cycle 2 & \multicolumn{1}{c}{ Cycle 1 } & \multicolumn{2}{c}{ Cycle 2 } \\
\hline Students who reach MCML & 26 & 28 & $81 \%$ & $88 \%$ \\
\hline Students who do not reach MCML & 6 & 4 & $19 \%$ & $12 \%$ \\
\hline
\end{tabular}

Based on table 2, learning using the MMP learning model combined with Dienes Learning Theory can increase the percentage of student learning outcomes that achieve MCML. In cycle 1 the number of students who got the learning outcomes exceeding MCML was 26 students with a percentage of $81 \%$. As for the value of student learning outcomes that do not reach MCML as many as 6 students with a percentage of $19 \%$. In cycle 2 there was an increase in students who got the value of learning outcomes above the MCML as many as 28 students with a percentage of $88 \%$, which means an increase of $7 \%$ from cycle 1 . Whereas for students who did not achieve the MCML there was a decrease to 4 students who did not get the value of the learning outcomes above MCML with a percentage of $12 \%$ which means there is a decrease in the number of students who do not reach the MCML by $7 \%$.

Based on the research that has been carried out, the learning process using the MMP model combined with the Dienes Game Theory has an impact on the learning outcomes of Grade VIII A students of SMP Negeri 06 Batu. There is an increase in the score of student learning outcomes in cycles 1 and 2 of the EST value determined as a reference value. The results in this study are in line with two previous studies where an increase in the value of student mathematics learning outcomes using the MMP learning model (Arifin, 2010). The learning process using Dienes Theory in Effective Junior High Schools (Atiqoh, 2014).

In the preliminary stage, the preliminary activity begins with the teacher greeting students and praying together according to their respective beliefs before starting the learning. Then the teacher checks the attendance of students and informs the material to be learned as well as informs how the learning will be carried out at the meeting at that time. Because the first meeting is the first time students get math subjects after school holidays, the teacher does not ask about homework or review previous meetings. But at the next meeting, the teacher asks about the material at the previous meeting.

The core activity begins with students creating 6 groups in each group consisting of 5-6 students of different gender following the teacher's direction. In the first meeting, the group division went smoothly, but in the second meeting, because there was an adjustment in-class hours and the class teacher came a little late, the students made the groups independently. When students make groups independently, learning feels less conducive because some students even chat with their group friends. The teacher also has to work extra to make the classroom atmosphere conducive back to the second meeting. Then students receive a picture of one type at the first meeting and a picture of a different type at the second meeting relating to learning material that is a number pattern. Students are asked to observe for a moment the pictures without opening the textbook first. After students try to observe the pictures provided and the curiosity begins to emerge in students, the teacher distributes student worksheets and glue. Students are asked to arrange the pictures into a pattern on the worksheet. The condition of students still really does not 
know what patterns are so students arrange these pictures spontaneously according to what is on their minds. After all, groups have finished drawing the pictures provided, students are then asked to read the textbook on a specific page at each meeting for 15 minutes individually as enrichment material. The teacher asks students to rearrange the pictures into a pattern following student understanding after reading the textbook. At the second meeting, students were asked to sort the pictures into a pattern and students immediately understood what they had to do based on the activities at the first meeting. In addition to drawing up pictures, some problems must be resolved by students in these 6 groups and the teacher helps groups that have difficulty solving problems.

The teacher observes the group that has solved all the problems in the worksheet correctly and quickly. Then the group representatives who have solved the problem at the worksheet represent the results of their group's work in front of the class to be understood also by other groups. The teacher should appreciate the fastest and most correct group that can solve all the problems in the worksheets by attaching the worksheets to the blank flipcharts and then stick them to the classroom wall. However, because the study was conducted a week after the school holidays ended, the supply of flipchart paper when the research was empty then the teacher still appreciated the group by giving applause and praise. The next step taken by the teacher after the whole group resolves the existing problems in the worksheet is to ask students to return to their initial seats and give individual test questions to class VIII A. Individual tests in class VIII A run smoothly according to what was planned in the lesson plan. Students work on the questions given independently.

To close the meeting, the teacher asks students to summarize what students understand from the material provided in learning. For the first meeting, the activities to summarize the learning material was canceled because indeed the time management carried out by the teacher and researcher was still ineffective. Much time is wasted on group formation, and solving problems with the worksheet. But at the next meeting, the problem has been resolved and students can summarize the learning material provided. The next activity is the teacher motivates students to keep their enthusiasm for learning, and asks students to prepare themselves for the next meeting by reading the next material. The teacher greets students before leaving the classroom.

\section{CONCLUSION}

Based on research conducted on July 23 to August 6, the following conclusions were found: (1) The implementation of the learning process by applying the MMP learning model combined with Dienes Game Theory runs smoothly in accordance with the RPP even though there are some things that are felt to be lacking, but can be improved before cycle 2 is complete. The game given to students in the form of drawing up images related to material number patterns can cause students to be enthusiastic in learning. Most students answered that the most memorable thing from the learning process was about the game of drawing up pictures that they had never found and about cooperation when solving problems in the worksheet. Students are enthusiastic when trying to solve the problems given to the worksheet and individual tests. Some students think that they want to use this learning model at subsequent meetings with mathematics teachers in class VIII A. (2) The average score of mathematics learning outcomes for class VIII A students who before using the MMP learning model combined with Dienes Game Theory only reached numbers 73.8 , after the application of this learning model can increase to 84.8 in cycle 1 and 86.0 in cycle 2 . The number of students who can get math learning outcomes above 
the MCML standard increases from cycle 1 which amounts to $26(81 \%)$ to 29 students in cycle $2(91 \%)$.

\section{REFERENCES}

Arifin, Zainal. 2010. Penerapan Model Pmebelajaran Missouri Mathematics Project (MMP) Untuk Meningkatkan Hasil Belajar Matematika Materi Pokok Fungsi Pada Peserta Didik Kelas VIII Mts Yasi Kronggen Brati Tahun Pelajaran 2010/2011. Skripsi S1 Tarbiyah. Institut Agama Islam Negeri Walisongo Semarang.

Atiqoh, Siti. 2014. Efektivitas Pembelajaran Berbasis Teori Belajar Zoltan Paul Dienes Terhadap Pemahaman Konsep Teorema Pythagoras Siswa Kelas VIII SMP. Skripsi S1 Pendidikan. Universitas Islam Sunan Kalijaga Yogyakarta.

Bildhonny, Achmad Furqon. 2017. Menurunkan Kejenuhan Belajar Siswa Dengan Teknik Relaksasi Pada Mata Pelajaran Pendidikan Jasmani.

Gningue, Serigne Mbaye. 2016. Remembering Zoltan Dienes, a Maverick of Mathematics Teaching and Learning : Applying the Variability Principles to Teach Algebra. City University of New York, September 2016.

Hakim, Lukman. 2016. Pemerataan Akses Pendidikan Bagi Rakyat Sesuai Dengan Undang-Undang Nomor 20 tahun 2003 Tentang Sistem Pendidikan Nasional. Edutech, Vol. 2 Maret, Tahun 2016 No.1 : 53-64.

Idrus, Muhammad. 2012. Mutu Pendidikan Dan Pemerataan Pendidikan Di Daerah. Psikopedagogia, Vol. 1 Desember, Tahun 2012 No.2.

Jannah, Ukhti Raudhotul. 2013. Teori Dienes Dalam Pembelajaran Matematika. Tahun 2018.

Karimah, Iffah. 9 April, 2018. Mengapa Matematika Sulit? . Kompasiana pos.

Karwati, Euis, dan Priansa, Donni Juni. 2015. Manajemen Kelas. Bandung : Alfabeta.

Kunandar. 2010. Langkah Mudah Penelitian Tindakan Kelas Sebagai Pengembangan Profesi Guru. Jakarta : Rajagrafindo Persada.

Mustajab, Nur amini, dan Shadiq, Fadjar. 2011. Dhoruri, Atmini dalam Penerapan Teori Belajar dalam Pembelajaran Matematika di SD. Yogyakarta : Pusat Pengembangan dan Pemberdayaan Pendidik dan Tenaga Kependidikan Matematika.

Rosyadi, Alfiani Athma Putri, Susanti, Reni Dwi, dan Dintarini, Mayang. 2016. Metodologi Penelitian Pendidikan. Malang : UMM Press.

Rusman. 2012. Model-model Pembelajaran. Depok : Rajagrafindo Persada.

Sanjaya, Wina. 2015. Penelitian Tindakan Kelas. Jakarta : Prenadamedia Group.

Shadiq, Fajar. 2009. Model-model Pembelajaran Matematika SMP. Yogyakarta : Pusat Pengembangan dan Pemberdayaan Pendidik dan Tenaga Kependidikan Matematika.

Sudijono, Anas. 2011. Pengantar Evaluasi Pendidikan. Jakarta : Rajagrafindo Persada. Sugiyono. 2016. Metode Penelitian Kuantitatif, Kualitatif, Dan R\&D. Bandung : Alfabeta. Thobroni, Muhammad. 2015. Belajar dan Pembelajaran: Teori dan Praktek. Yogyakarta : Arr-Ruzz Media.

Zulyadaini. 2016. Perbandingan Hasil belajar Matematika Model Pembelajaran Kooperatif Tipe Coop-coop Dengan Konvensional. Jurnal Ilmiah Universitas Batanghari Jambi. Vol. 1, Tahun 2016 No.1 : 153-158 